\title{
Simply Paradigm of Da'wah Character In Facing Neurotechnology Era
}

\author{
Nanang Kuswara \\ Prodi Manajemen Dakwah \\ Fakultas Dakwah Institut PTIQ Jakarta, Indonesia \\ nanang.kuswara@ptiq.ac.id
}

\begin{abstract}
Since year 569 M, da'wah character has been organized around the exchange paradigm. Da'wah character for postindependence period, was faced with the life of Islam history which had been confessed as a cultural power. The concepts apply to all forms of exchange, as Al-Qur'an is compatible to all centenaries and places. Whether it is communicated by speaking efforts (bi al-lisan), writing (bi al-qalam), or by doing (bi al-hal). Da'wah character paradigm evolved from a verbal-conventional oriented view, physical efforts, and to expand to the highest network level of information technology system called neurotechnology. This paper use a literatur studies from the references that relevances with this theme. Theoretically, this article is developing of a three-tiered discourses of the emerging field of da'wah characters are explored - its sub phenomenon (Muslim sensory models), its phenomenon (da'wah character networks), and its super phenomenon (sustainability and development). The result of this article that consequently the relational theories have come to the fore. But even as the field struggles to grasp its new fields of explanation, there is a paradigm shift happening at its boundaries. The shift significantly integrates the da'wah character worldview by the theoretical tools and methodologies in frame syummuliyah and 'alamiyah and based on Al-Qur' an and hadist (rabbaniyah), absolutly.
\end{abstract}

Keywords: character, paradigm, da'wah,neurotechnology, era

\begin{abstract}
Abstrak
Sejak tahun 569 M, karakter dakwah telah diatur di sekitar paradigma pertukaran. Tokoh dakwah untuk periode pasca kemerdekaan, dihadapkan pada kehidupan sejarah Islam yang telah diakui sebagai kekuatan budaya. Konsep-konsep ini berlaku untuk semua bentuk pertukaran, karena Al-Qur'an kompatibel untuk semua seratus tahun dan tempat. Apakah itu dikomunikasikan dengan upaya berbicara (bi al-lisan), menulis (bi al-qalam), atau dengan melakukan (bi al-hal). Paradigma karakter dakwah berevolusi dari pandangan berorientasi verbal-konvensional, upaya fisik, dan untuk memperluas ke tingkat jaringan tertinggi dari sistem teknologi informasi yang disebut neuroteknologi. Makalah ini menggunakan studi literatur dari referensi yang relevan dengan tema ini. Secara teoritis, artikel ini mengembangkan wacana tiga tingkat dari bidang yang muncul dari karakter dakwah dieksplorasi - sub-fenomena (model sensor Muslim), fenomena (jaringan karakter dakwah), dan fenomena super (keberlanjutan dan pengembangan). Hasil artikel ini bahwa akibatnya teori relasional telah mengemuka. Tetapi bahkan ketika lapangan berjuang untuk memahami bidang penjelasannya yang baru, ada pergeseran paradigma di batas-batasnya. Pergeseran ini secara signifikan mengintegrasikan pandangan dunia dakwah karakter
\end{abstract}


dengan alat teoretis dan metodologi dalam bingkai syummuliyah dan 'alamiyah dan berdasarkan Al-Qur'an dan hadis (rabbaniyah), secara absolut.

Kata kunci: karakter, paradigma, dakwah, neuroteknologi, era

\section{Introduction}

A number of prominent Indonesian scholars have analyzed the evolution of the da'wah character in various perspectives, stages, and moments. One of those scholars was Harun Nasution (1992) whomentioned thatda'wah has contributed to generate Islam prevailed and progressed in all fields for hundreds of years, though on the other hand it has been declining. ${ }^{1}$ In the first period of da'wah, Muhammad had his own power of interpersonal communication. And one of the strongest points owned by Muhammad to be a leader was to communicate to the people with their language. Another point which contributed to his role as a prophet was his own characters such as shiddiq, amanah, tabligh and fathanah. Those personal points strongly supported his leadership role. No wonder, in this period, Muhammad was able to actuate his characters perfectly by being truthful verbally and behaviorally, maintaining trustworthiness, disseminating the message, generating wisdom and intelligent.

Related to Muhammad individual role as mentioned above, Islam as a religion which has its beliefs in worship (hablumminallah) and by way of life behavior (hablumminannas) had been successfully to be communicated to the mankind. The paradigm of da'wah characterin this period was determined by the strength of Muhammad as an individual person and a leader who had complete competencies and able conveying the messages with clear and understood language. The language was the instrument to articulate the da'wah character issues. On this basis, every prophet was sent to his people by speaking their mother tongue. ${ }^{2}$ This statement was revealed in the holy Qur'an: "We never sent a prophet, but with the language of his people, so that he can explain clearly to them. So, God astray whom He pleases, and gives guidance to which He will, and He is God Almighty, the Wise." 3

In the dissemination process, as stated by Ricklefs (1991), Islam had been introduced to Indonesia by Muslim Traders who came to Southeast Asia through silk-link. It was in the third caliph of Islam, Uthman $(644-656) .{ }^{4}$ And then later Islam reached and took part of the majority of the religion followers in Indonesia which based on census data, from 103,579,496 in 1971 to $177,528,772$ in followers 2000..$^{5}$ Uniquely, Muslims are

\footnotetext{
${ }^{1}$ Beti Yanuri Posha, "Perkembangan Islan di Indonesia Pasca Kemerdekaan", Jurnal Historia, Vol. 3 No. 2, (2015), 75.

2 Amal Ibrahim Abd El-Fattah Khalil, "The Islamic Perspective of Interpersonal Communication", Journal of Islamic Studies and Culture, Vol. 4 No. 2 (2016), 22.

${ }^{3}$ See QS. Ibrahim: 4

${ }^{4}$ Erwin Hafid, "The Early of Islam in Indonesia", Journal of JICSA, Vol. 1 No. 2, 2012, hal. 1

${ }^{5}$ Houssain Kettani, “World Muslim Population: 1950 - 2020", International Journal of Environmental Science and Development (IJESD), Vol. 1, No. 2, 2010, 6.
} 
found on all five inhabited continents, more than $60 \%$ of the global Muslim population is in Asia. ${ }^{6}$

According to historical receptiveness, Indonesia has some of the richest and most diverse traditions in the Islamic world. The founding traditions of Islam in Indonesia derive from a variety of sources - the Arab world, Persia, India and, as is becoming increasingly evident, from the Muslim trading communities of southern China. ${ }^{7}$

The above way had been becomingly a proven that da'wah character had been developing through commercial activities, such as trading. So, in the point of comprehensive paradigm, the tendency to view Islam not merely as a "religion" in the narrow sense of theological belief, private prayer and ritual worship, but also as a total way of life with guidance for political, economic, and social behavior. ${ }^{8}$ Although had to be initially mixed with syncretism, as stated by Nurcholis Madjid that Islam in Indonesia had spread out very fast, widely, and well- established. However, in this period Islam was full of romanticism to the glory of Hindu and Buddha Kingdoms. ${ }^{9}$

That was why Islam received in Indonesia without violence. In the war of independence period, da'wah character was situated and became a tool to motivate Indonesian people to fight for independence. As known that The Indonesian National Revolution, or Indonesian War of Independence (Indonesian: Perang Kemerdekaan Indonesia; Dutch: Indonesische Onafhankelijkheidsoorlog), was an armed conflict and diplomatic struggle between the Republic of Indo- nesia and the Dutch Empire and an internal social revolution during postwar and postcolonial Indonesia. It took place between Indonesia's declaration of independence in 1945 and the Netherlands' recognition of Indonesia's independence at the end of $1949 .{ }^{10}$

At that time 'Ulamas declared that fighting for independence was jihad. Noted as a history that on $21^{\text {st }}$ and $22^{\text {nd }}$ from whole of Java and Madura had a declaration in Surabaya to state of war independence as a Jihad resolution. Nugroho Notosusanto et al filed that TKR supported by the youth had attacked the British Army Posts in Padang and Bandung on $24^{\text {th }}$ of November $1945 .{ }^{11}$ With only utilized sharpened bamboos,

\footnotetext{
${ }^{6}$ Mapping the Global Muslim Population, A Report on the Size and Distribution of the World's Muslim Popula- tion, (Pew Forum on Religion \& Public Life 1615 L St., NW, Suite 700 Washington, D.C.0036-5610), 1.

7 James. J.Fox, Currents in Contemporary Islam in Indonesia, Paper Originally presented in Harvard Asia Vision, April, 29 - May, 1, Cambridge , Mass, 2004, 2.

8 William E. Shepard, Islam and Ideology: Towards a Typology, International Journal of Middle East Studies, (Published by: Cambridge University Press, Vol. 19, No. 3, 1987), 308.

${ }_{9}^{9}$ Abdul Ghofur, Tela'ah Kritis Masuk dan Berkemban- gnya Islam di Indonesia, Jurnal Ushuluddin, Vol. XVII No. 2, (2011), 60.

${ }^{10}$ https://en.wikipedia.org/wiki/Indonesian_National_Revolution - Accessed on March 5th 2018

${ }^{11}$ Miftahuddin. Menuju Kemerdekaan sampai Masa Perang Mempertahankan Kemerdekaan (19361949), Laporan Penelitian Payung Universitas Negeri Yogyakarta, 2012, 4.
} 
Indonesia youth had theirown beliefs of Allah and bravely struggled to get their independence.

Da'wah character for postindependence period, was faced with the life of Islam history which had been confessed as a cultural power. However, Islam was prevented to design the nation of Indonesia according to Islam version. As moral and cultural power, the existence of Islam was recognized, however it was not calculated in term of real political power. And then Islam development in the period of old-order (Orde Lama) had been positioned in paradoxical configuration, mainly in political activities. While in the period of neworder (Orde Baru), Islam seemed to be recognized as a moral base to the nation and state development only. ${ }^{12}$ Ironically, at the end of new-order power, three Islamic Scholars such as Nurcholis Madjid, Amien Rais, and Malik Fadjar dominantly designed the reformation concepts of State of Indonesia. ${ }^{13}$

Moslem experiences in different decades and century as described above, showed that Islam teachings had covered every single point of empirical human life, and it compatibles to any changes of times and places and even to be aligned with neurotechnology era as well. Neurotechnology as a set of devices used to understand neural processes and applications that can potentially facilitate the brain's ability to repair itself, ${ }^{14}$ has the potential to generate major ethical, legal and social issues, including the paradigm of da'wah character. In this case, Moslem scholars had reinterpreted and re-formulated to bring up Islamic concepts which are relevant to the currents demands as an embodiment of motto that Islam "shalihun li kulli zaman wa makan". ${ }^{15}$

Another issue extracted from various Muslim sensory capabilities in facing the past and current crucial great events as previously described, that da'wah activities have been becomingly a tool for Islam to be a trend-setter and even problem solver in every moment of truth within mankind empirical life. This point indicates that da'wah character requires updated paradigm, to ensure that the values of Islam teachings are correctly and compatibly communicated and implemented. In this case, da'wah character is about communication character. And Al-Qur'an and Hadith have perfectly directed that communication character is able to be conveyed easily using the rules, principles, or communication ethics in Islam perspective. Either utilizes intra personally communication or inter personally one. ${ }^{16}$

${ }^{12}$ Beti Yanuri Posha, Perkembangan Islam di Indonesia Pasca Kemerdekaan, 2015, hal. 77

13 https://serbasejarah.files.wordpress.com/2012/12/ setelah-dia-pergi-soeharto.pdf Tempo Edisi Khusus Suharto, Madu dan Racun Sepuluh Tahun Lalu, hal. 23 - access on March 16 ${ }^{\text {th }}, 2018$

${ }^{14}$ Susan W. White, John A. Richey, Denis Gracanin, Martha Ann Bell, Stephen LaKonte, Marika Coffman, Andrea Trubanova, Inyoung Kim, The Promise of Neurotechnology in Clinical Translational Science, HHS Public Accsess, Publised in 2014, access on March 16 ${ }^{\text {th }}, 2018$

${ }^{15}$ John L. Esposito, The Oxford Encyclopedia of the Modern Islamic World, Volume IV, (New York:Oxford University Press), 1995, 13 - 18.

${ }_{16}$ Andi Faisal Bhakti \& Venny Eka Meidasari, “Trendsetter Komunikasi di Era Digital: Tantangan dan Peluang Pendidikan Komunikasi dan Penyiaran Islam", Jurnal Komunikasi Islam , Vol. 04 No. 01, 


\section{Theoretical Frame}

\section{Literature Reviews}

This research is based on previous research from Mubasyaroh (2015) preaching in Mecca at the time of the Prophet had eschatological or divine characteristics because the Arab community at that time did not force God (Allah), also had characteristics including; in the fields of knowledge, coaching and planning. ${ }^{17}$

In other journal, this article based on research from Rafael Yoeste, Sara Goering, et al that reported that among the various efforts to address this in AI, the IEEE Standards Association created a global ethics initiative in April 2016, with the aim of embedding ethics into the design of processes for all $\mathrm{AI}$ and autonomous systems. History indicates that profit hunting will often trump social responsibility in the corporate world. And even if, at an individual level, most technologists set out to benefit humanity, they can come up against complex ethical dilemmas for which they aren't prepared. The possible clinical and societal benefits of neurotechnologies are vast. To reap them, we must guide their development in a way that respects, protects and enables what is best in humanity. ${ }^{18}$

\section{The Sub-Phenomenon of Moslems Sensory Model : Neurotechnology}

With this model, Islam is acknowledged, impregnated, interpreted, and applied by mankind from generation to generation in the whole order of human life.On the contrary, Islam will just simply disappear in term of teachings perspective and leave only the meaningless name among other ideologies, if da'wah activities are not correctly manageable. Therefore, da'wah character in Islam is crucial sensory model in the whole of Islam teachings in this neurotechnology era. It is a kind of messenger blast technology of AlQur'an in spreading out the messages. According to Vogeley and Gallagher (2011) neurotechnology raises ethical questions that are associated with what we call our "self" or "soul," complex philosophical concepts with many presuppositions. ${ }^{19}$ Whereas, Merkel et al. (2007) suggest that the ethical debate usually draws on the concept of personhood as a "modern" notion that includes core aspects that we typically ascribe to our self or soul . These include self-consciousness, responsibility, planning of the individual future, and similar dimensions. In our deliberations, we should first make ourselves aware of the notions of "person" and "personal identity" as fundamental concepts of ethics. Integrity and

Juni 2014, 22.

${ }^{17}$ Mubasyaroh, "Karakteristik dan Strategi Dakwah Rasulullah Saw pada Periode Makkah", ATTABSYIR: Jurnal Komunikasi Penyiaran Islam, Vol. 3, No. 2 Desember 2015.

${ }^{18}$ Rafael Yoeste, Sara Goering, et al, "Four Ethical Priorities for Neurotechnologies and AI". Nature : International Weekly Journal of Science, Volume. 551, Issue. 7679. 2017. 08 November 2017

${ }^{19}$ Vogeley K., Gallagher S. Self in the Brain in The Oxford Handbook of the Self, ed Gallaher S. (Oxford: Oxford University Press; 2011), 111-136. 
dignity of a person are the most relevant criteria for the ethical evaluation of technological interventions. ${ }^{20}$ Moreover, Beauchamp and Childress (2008) states that the concept of personhood always has normative implications, because we not only describe certain attributes and capabilities of a person, but we want to have them recognized, acknowledged and guaranteed. For example, the principle of "informed consent," which is so important in clinical practice, refers to the notion of personhood. Patients must consciously authorize a neurotechnological intervention before it is conducted. Along similar lines, the concept of a person can provide an ethical benchmark, assuming that we do not want to impair personal capabilities such as autonomy and responsibility by interventions in the brain. Neurotechnological interventions are ethically not acceptable if remaining a person is at risk. The current practice of neurotechnological interventions is, explicitly and implicitly, orientated toward the concept of personhood. ${ }^{21}$

\section{Da'wah Character Network Approach}

In building the character of da'wah based on three characteristics: rabbaniyah (monotheism), syumuliyah (comprehensive), and alamiyah (universal). This means that the character is derived directly from the principles of monotheism in the Qur'an. Because, according to Ilyas Ismail and Prio Hotman, the da'wah is a "gap in hand" from Islamic teachings. Clearly, da'wah is a medium in manifesting the concept of Islam which was originally in the form of ideas (abstract) in the form of concrete-empirical on the order of practical community life. Therefore, da'wah must have congruent characteristics and even reflect Islam as a paradigm. ${ }^{22}$

In da'wah character concept of the current situation can be identified in tree prespective : behaviouristic perspective is community behaviour is influenced by only universal materialistic achievement ; transmissional perspective is a process of transmission of Islam teachings from $d a^{\prime} i$ as communicator to mad'u as receiver; ${ }^{23 i n t e r a c t i o n ~ p e r s p e c t i v e ~ i s ~}$ da'wah activity called Islamic communication, where social interaction happened and norms are formed according to the message of da'wah. ${ }^{24}$

\section{Analysis and Implication}

In da'wah character networks pproach, However, authorities in da'wah management need to build a da'wah character network or system to ensure that da'wah management to be implemented appropriately. For da'wah practitioners, a solid network is able to plan, to

${ }^{20}$ Merkel R., Boer G., Fegert J., Galert T., Hartmann D., Nuttin B., et al. Intervening in the Brain. Changing Psyche and Society. (Heidelberg: Springer, 2007)

${ }^{21}$ Beauchamp T. L., Childress J. F. Principles of Biomedical Ethics. (Oxford: Oxford University Press, 2008)

${ }^{22}$ Abdullah Nasih Ulwan, Silsilah Madrasah al-Du'at, (Kairo : Dar al-Hadith, 2004), 16.

${ }^{23}$ Ziauddin Sardar, Tantangan Dunia Islam Abad 21 Menjangkau Informasi, (Bandung: Mizan, 1996), 1617.

${ }^{24}$ Malik Idris, Strategi Dakwah Kontemporer, (Makassar: Sarwah Press, 2007), 111. 
coordinate, to direct, to control and to evaluate the activities of da'wah. Those functions of da'wah management become tools to build unity of command to avoid partial da'wah models and actions which might be implicate to decrease the height of Islamic teachings.

According to theory of sub-phenomenon: Moslems Sensory Model, Islam is Allah's teachings which perfectly designed to be easily conveyed to manage mankind individually and collegially. Unfortunately, it is only an idea and a wishful thinking if the teachings are not comprehensively communicated to the mankind, espe- cially if that transcendental ideology is not correctly applied in human empirical life. Therefore, da'wah character in Islam is crucial sensory model in the whole of Islam teachings in this neurotechnology era. It is a kind of messenger blast technology of Al-Qur'an in spreading out the messages. With this model, Islam is acknowledged, impregnated, interpreted, and applied by mankind from generation to generation in the whole order of human life.

On the contrary, Islam will just simply disappear in term of teachings perspective and leave only the meaningless name among other ideologies, if da'wah activities are not correctly manageable. In this issue, Muslims have to cling firmly to what Allah delivers as an obligation order to manage da'wah to the ones that expect to be the lucky ones in their life as He mentioned: "let there arise out of you a band of people inviting to all that is good, enjoining what is right, and forbidding what is wrong: they are the ones to attain felicity". ${ }^{25}$

Da'wah as an obligation order, becomingly the most crucial efforts since the spiritual strength of Muslims is recently getting weaker. This situation is gradually caused by leaving Islam teachings in many aspects which im-plicates to the social and cultural decline. And the only social and cultural decline is a reality as Muslims ignore the soul of the teachings of Islam. Islam is a religion, and the weakening of Muslims to practice the religion is caused by the disappearance of their sixth sense, the sensory of religion. Religion is always assumed to be contrary to the modernity. The difference of this perception is able to be analyzed by two factor dichotomies, between religion as a subjective reality and modernity as an objective reality. ${ }^{26}$ In the perception of modern mankind, religion is considered as a non-relevant guidance anymore, since metaphysic paradigm had been being crashed by positivism paradigm. Means, that religion is the past, and now is positivism era. ${ }^{27}$

However, the paradoxical issues happened in modernism is that instrumental ratio and technical ratio which had been offering science and technology as an enlightenment of human life in many aspects, extra- ordinarily caused negative implications to human civilization. Like brought up Adanma (2015) in his research in Nigeria, found out that technology influences the current degeneracy of morality,

${ }^{25}$ See QS. Ali Imran: 104

${ }^{26}$ Nur Ahmad, "Konseling Agama: Terapi Terhadap Pengidap Penyakit Manusia Modern", Konseling Religi: Jurnal Bimbingan Konseling Islam, Vol. 5, No. 1, Juni 2014, 153.

${ }^{27}$ https://www.britannica.com/topic/positivism 
criminality, and violence. ${ }^{28}$ Younes \& Al-Zoubi (2015) discovered another reality of the most important negative impacts of the use of modern technologies on society and impact on individual behavior, those are: the formation of personal beliefs, social isolation, reduction in the family ties between the family and society members, inactivity, obesity, lack of desire to work different kinetic activities, a waste of time in things that are not useful, increase in the rate of violence, especially in children because of watching violent programs, high crime rate because of spreading video clips presenting all kinds of these crimes and ways of committing them and the spread of lies and rumors causing distraction and loss of trust in such information.

These crimes and ways of committing them and the spread of lies and rumors causing distraction and loss of trust in such information. ${ }^{29}$ However, science and technology had not been only creating negative implications, but also positive results. Science and technology has changed society throughout history. Over the last few decades, cellular phones such as Samsung, Nokia, Black Berry, computers, and most importantly the internet have completely overhauled the way people interact in society. In schools, as a part of specifically da'wah management in maximizing the quality of next Muslim generation, technology implementation is pivotal to student success post high school due to the changing times and high demands for tech qualified person.

It is imperative that teachers of the $21^{\text {st }}$ century adjust to the tech-nological revolution and not only prepare themselves but prepare their students for the technological real world. Technology has changed the way society looks, and the way the classroom looks and there will be no return to chalk boards and writing letters. The $21^{\text {st }}$ century society demands a technologically advanced person and the $21^{\text {st }}$ century classroom requires the same. ${ }^{30}$

Concerning to the positiveof science and technology impacts, science (and technology) in the perspective of Islam is wisdom. Islam looks up the science, that was why the first statement of Allah's order was to read in the name of Lord and Cherisher Who created, created man, out of a (mere) clot of congealed blood, read and Lord is Most Bountiful, He Who taught (the use) the pen, taught man that which he knew not. ${ }^{31}$ As wisdom, science and technology are able to be utilized as devices to reach the objectives of human desires. And they are also crucial variables and the key to lead universal civilization, and Muslims have obligation to be the best people as required by Allah as He mentioned "you are the best of peoples, evolved for

\footnotetext{
${ }^{28}$ Adanma C. Eberendu, Negative Impacts of Technolo- gy in Nigerian Society, International Journal of Business and Management Review, Published by European Cen tre for Research Training and Development UK (www. eajournals.org), Vol.3, No. 2, 2015, 29.

${ }^{29}$ Mohammad Bani Younes \& Samer Al-Zoubi, The Impact of Technologies on Society: A Review, IOSR Journal Of Humanities And Social Science (IOSR-JHSS), Vol. 20, Issue 2, Ver. V, 2015, 82.

${ }^{30}$ Brian P. Sutton, The Effects of Technology in Society and Education, $A$ Thesis submitted to the Department of Education and Human Development of the State Univer- sity of New York College Spring 2013, 4.

${ }^{31}$ See QS. 96: 1 - 5
} 
mankind, enjoining what is right, forbidding what is wrong, and believing in Allah. ${ }^{32}$

Therefore, in principles science and technology are parts of Islamic teachings which have to be obligatorily controlled and applied by Muslims within their empirical life. Science and technology in one side and religion in another side, just like two sides of the same coin. Islam does not differentiate between matters of state and matters of religion. The pursuit of knowledge in Islam can prove the link between science and religion. ${ }^{33}$ Therefore, Islam prioritizes science as well as technology in advancement of civilization and the Islamic da'wah. ${ }^{34}$

Islam teachings comprehensively designed by Allah to be available and compatible at all times and places to be guidance and answers for whole of mankind problems. Unfortunately, Muslims have various and different sensory of religion to solve the problems and response to the challenges as well as universal interactions. Science and technology as represented by the west, partake in common bonding cultures, Muslims and Westerners can coexist if a clash of symbols is not mistaken for a clash of substances. Preventing this cognitive error is possible, provided that spokespersons for Muslims and Westerners act to demystify conflicts and emphasize cultural commonalities while accommodating differences, and differentiate between constructive and destructive means of redressing grievances.

Many existing problems between Muslims and Westerners have much less to do with religion or culture than with nationalism. ${ }^{35}$ The quality of Muslims sensory of religion in this context has actually to prefer to what Allah guided in His statement:

"O mankind! We created you from a single (pair) of a male and a female, and made you into nations and tribes, that you may know each other (not that you may despise each other). Verify the most honoured of you in the sight of Allah is (he who is) the most righteous of you. And Allah has full knowledge and is well acquainted (with all things).

In Da'wah Char acter Networks Approach, since the reformation order started in 1998, the character of all media, especially televisions, in Indonesia had totally changed. The programs became more vulgar, open, and informatively communicated for whole channels. Therefore, TV became a main source and tool for da'wah. The discretion of da'wah packaging programs was able to be more vary and interesting to be developed in order to maintain the sustainability of da'wah. In one side, this phenomenon has raised a great hope for Islam as a religion to uphold the appreciation of universal truth values. The explosion of TV program information can be utilized as media delivery and dissemination of Islam values to the people openly and widely.

32 See QS. 3: 110

${ }^{33}$ Toshiyuki Akiyama, Islamic Perspective on Science and Technology: An Essay on Interrelations between Science and Technology in Islam, IMES Working Papers Series No. 13, The Institute of Middle Eastern Studies of International University of Japan, Year 1998, 45.

34 Yedi Purwanto, Islam Mengutamakan Ilmu Pengetahuan dan Teknologi, Jurnal Sosioteknologi ITB, Edisi 22 Tahun 10, 2011, 1043.

${ }^{35}$ Nathan C. Funk and Abdul Aziz Said, Islam and the West Narratives of Conflict and Conflict Transformation, International Journal of Peace Studies, Volume 9, Num ber 1, Spring/Summer 2004, 16. 
Currently, not only TV which is able to be accessed for da'wah purposes, but various models and brands of smart phones becomingly hand-carry and the most usable gadget. As if, the people can't live without it. People movement not just from hear, see, and read the contents, but also critically comment and form their paradigm. People not just recognize and embrace single value, they are able to choose and rate and in the end to decide to receive or to leave what they like or they don't like. On this point, the question is, whether the people to decide da'wah bargaining value or da'wah has to herds people to the choice they have to receive? In this case Fatmawati (2009) stated that the answer is not so simple.

The explosion of information in the media has not been stoppable and becomingly a point of values formation. This phenomenon has to be responded wisely by da'wah practitioners. ${ }^{36}$ However, authorities in da'wah management need to build a da'wah character network or system to ensure that da'wah management to be implemented appropriately. For da'wah practitioners, a solid network is able to plan, to coordinate, to direct, to control and to evaluate the activities of da'wah. Those functions of da'wah management become tools to build unity of command to avoid partial da'wah models and actions which might be implicate to decrease the height of Islamic teachings.

Islam is a da'wah religion which has to be socialized and transformed wisely and prudently, with love and affection, politely and peacefully, democratically persuasively, in order to position comprehensively people in happiness and prosperous. ${ }^{37}$ Therefore, one of the points need to be taken care is the character of dakwah, not only in Indonesia which has an official national motto of Indonesia, "unity in diversity", means out of many, one, ${ }^{38}$ but also universally.

Azyumardi mentioned that da'wah practitioners who have flaming religious attitudes can trigger conflicts. ${ }^{39}$ Therefore, the role of network on da'wah character is crucially required to ensure that da'wah is correctly implemented according to what Allah stated in His verse: "Invite (all) to the Way of your Lord with wisdom and beautiful preaching: and argue with them in ways that are best and most gracious".40

As known, Islam is a religion which has not only one aspect in its teachings, but many aspects, such as theology, ritual, moral, politic, history, mysticism, and many others. And communicating those aspects into empirical human life need to study it from many approaches and discipline of science to color the perfectly values of Islam. ${ }^{41}$ And it

\footnotetext{
${ }^{36}$ Fatmawati, Paradigma Baru Mengemas Dakwah Melalui Media televise di Era Globalisasi, Jurnal Dakwah dan Komunikasi, STAIN Purwokerto, Vol. 3 No. 2, 2009, 185.

37 Arsam, Monitoring dan Evaluasi Dakwah: Studi terhadap Kegiatan Dialog Interaktif Takmir Masjid Ash-Shidi, At-Tabsyir Jurnal Komunikasi Penyiaran Islam, Vol. 1 No. 1, 2013, 159.

38 Soewito Sutasoma Santoso, Study Old Javanese Wa- jrayana, New Delhi, International Academy of

Culture, 1975, 578. - accessed on 18 ${ }^{\text {th }}$ of March 2018 from ttps://en.m.wikipedia.org

${ }^{39} \mathrm{http}: / /$ www.republika.co.id/berita/dunia-islam/islam-nusantara/16/12/07/ohtm9k396-kelom

pok-ag- ama-agar-punya-sensitivitas - accessed on March $18^{\text {th }}, 2018$

${ }^{40}$ See QS. 16: 125

${ }^{41}$ Muhammad Rajab, "Dakwah dan Tantangannya dalam Media Teknologi Komunikasi”, Jurnal
} 
needs a solid of networking of da'wah character.

In Super Phenomenon: Sustainability and Development, spesifically in agrarian era, the roles of religious leaders were so strong to influence the empirical life of society. The opinions of ulamas, namely kyais, buyas, Tuan Gurus or Ajengans as religious leaders were imitated, heard and implemented. In this current modern era, da'wah is not dominated by religious leaders anymore. Internet becomingly the most easiest way to get the knowledge of Islam teachings. This shift of da'wah character is inevitable. The presence of modernization according to Anthony Giddens (1990:39) a necessity that cannot be denied. ${ }^{42}$

One of current modern issues is neurotechnology which is a rapidly advancing field, with potential impacts that could far surpass those of the information revolution. Therefore, da'wah character has to be redesigned to readily face the neurotechnology era. The goal is not to learn about neurotechnology in a specific way, but rather to define possible benefits, burdens, risks and problems, enable preparedness, and preclude potentially negative effects.

It is too complicated for dakwah character to involve in neurotechnology process in detail. Therefore, the only way to behave is to design the strategies and define the paradigm of da'wah character. Renewal of da'wah characters in neurotechnology era is an urgent doctrine socialization agenda. The conceptual vision has to be reformed to correspond with socio-cultural change and focus to the problems and challenges of all dimensions. This is a structure which sometimes contradictorily with an urgency of especially dignity of humanity, since the hegemony of modernism cultural identity becomes stronger and stronger. Therefore, the paradigm of da'wah character has to comprehensively cover all dimensions of human interests.

Setting up da'wah character might be up to the challenges of the current situation. One of the challenges is behaviouristic perspective. Nowadays, community behaviour is influenced by only universal materialistic achievement, and the objective of da'wah is behaviour change of community to be the best of society. Another challenge of da'wah is transmissional perspective. Dakwah is a process of transmission of Islam teachings from $d a^{\prime} i$ as communicator to $\mathrm{mad}^{\prime} u$ as receiver. So, when the teachings is trasmitted to the society as object, then the role of media model becomingly very decisive aspect. Muslims expertise in neurotechnology system need to be urgently developed.

Ziauddin Sardar stated that the revolution of information system has been creating special challenges and Muslims need to utilize it to achieve the objectives of da' $a$ ah. And then the last challenge of dakwah is interaction perspective. As stated by Malik Idris that da'wah activity has special communication called Islamic communication,

Dakwah Tabligh, Vol. 15 No. 1, 2014, 72.

${ }^{42}$ Abdul Basit, “Dakwah Cerdas di Era Modern”, Jurnal Komunikasi Islam, Vol. 3 No. 1, 2013, 77. 
where social interaction happened and norms are formed according to the message of da'wah. The most challenge faces by da'wah character is at the same time the society also become object of other parties for whatever purposes, and might not deliver good messages. ${ }^{43}$

\section{Conclusions}

Responding to the mentioned challenges as described above, the paradigm of da'wah character comes to the three main conclusions: (1) for any situation, the cord of Islamic ethic is Tawheed (rabbaniyah) that involved syumuliyah and alamiyah. All human activities such as moderation, freewill and responsibility have to be based on "because of Allah"; ethics and moral from Islamic perspective is akhlaq or the state of feelings that shapes human behavior. Thus, to shape the akhlaq, Muslims have to practice the characteristic of the Prophet Muhammad such as siddiq, amanah, tabligh, fathanah in any situation of empirical life; upholding the concept of "al- Islamu ya'lu wa laa yu'laa 'alaihi" by implementing the whole Islamic teachings, including to be the best society in especially harmonizing the teachings with the current and future actual human life. This paper simply illustrates regarding Islamic da'wah character in facing real neurotechnology era. Recommendation for further research is to study the correlation between Islamic da'wah character and the potential of an Islamic financial technology as an entrepreneurship activities toward da'wah bil hal.

\section{Bibliography}

Akiyama, Toshiyuki, Islamic Perspective on Science and Technology: An Essay on Interrelations between Science and Technology in Islam, IMES Working Papers Series No. 13, The Institute of Middle Eastern Studies of International University of Japan, Year 1998.

Arsam, Monitoring dan Evaluasi Dak- wah: Studi terhadap Kegiatan Di- alog-Interaktif Takmir Masjid Ash-Shidi, At-Tabsyir Jurnal Komunikasi Penyiaran Islam, Vol. 1 No. 1, 2013.

Ahmad, Nur, Konseling Agama: Terapi Terhadap Pengidap Penyakit Manu- sia Modern, KONSELING RELIGI: Jurnal Bimbingan Konseling Islam, Vol. 5, No. 1, Juni 2014.

Bhakti, Andi Faisal., Eka Meida- Sari, Venny, Trendsetter Komunikasi di Era Digital: Tantangan dan Peluang Pendidikan Komunikasi dan Penyiaran Islam, Jurnal Komunikasi Islam, Vol. 04 No. 01, Juni 2014.

Beauchamp T. L., Childress J. F. Principles of Biomedical Ethics. Oxford: Oxford University Press. 2008

\footnotetext{
${ }^{43}$ Ratnah Umar, "Metode Dakwah di Era Globalisasi", Jurnal Al-Tajdid STAIN Palopo, Vol. 1, 2016 accessed on $19^{\text {th }}$ of March, 2018
} 
Eberendu, Adanma C. Negative Impacts of Technology in Nigerian Society, International Journal of Business and Management Review , Published by European Centre for Research Train- ing and Development UK (www. eajournals.org), Vol.3, No. 2, 2015.

Esposito, John L., The Oxford Ency-clopedia of the Modern Islamic World, VolumeIV,New York:Oxford University Press, 1995.

Fatmawati, Paradigma Baru Mengemas Dakwah Melalui Media televise di Era Globalisasi, Jurnal Dakwah dan Komunikasi, STAIN Purwokerto, Vol. 3 No. 2, 2009.

Fox, James J. Currents in Contemporary Islam in Indonesia, Paper originally presented at Harvard Asia Vision 21, Cambridge Mass, 29 April - 1 May, 2004.

Funk, Nathan C., Said, Abdul Aziz, Islam and the West Narratives of Conflict and Conflict Tran formation, International Journal of Peace Studies, Volume 9, Number 1,Spring/Summer 2004.

Ghofur, Abdul, Tela'ah Kritis Masuk dan Berkembangnya Islam di Indonesia, Jurnal Ushuluddin, Vol. XVII No. 2, 2011.

Idris, Malik, Strategi Dakwah Kontemporer, Makassar: Sarwah Press, 2007, hal. 111

Kettani, Houssain, World Muslim Population: 1950 - 2020, International Journal of Environmental Science and Development (IJESD), Vol. 1, No. 2, 2010.

Khalil, Amal Ibrahim Abd El-Fattah, The Islamic Perspective of Interpersonal Communication, Journal of Islamic Studies and Culture, Vol. 4 No. 2, 2016.

K. Vogeley., Gallagher S. Self in the Brain in The Oxford Handbook of the Self, ed Gallaher S. Oxford: Oxford University Press; 2011, p. 111-136.

Mapping the Global Muslim Population, A Report on the Size and Distribution of the World's Muslim Population, Pew Forum on Religion \& Public Life 1615 L St., NW, Suite 700 Washington, D.C.0036-5610.

Miftahuddin, Peran Organisasi Islam dari Perjuangan Menuju Kemerdekaan sampai Masa Perang Mempertahankan Kemerdekaan (1936-1949), Laporan Penelitian Payung Universitas Negeri Yogyakarta, 2012.

Mubasyaroh, Karakteristik dan Strategi Dakwah Rasulullah Saw pada Periode Makkah, ATTABSYIR: Jurnal Komunikasi Penyiaran Islam, Vol. 3, No. 2 Desember 2015,

Prabowo S, M. Nur, Respon Agama Terhadap Kultur Modernitas: Perspektif Perenialisme, Jurnal Rasail, Vol. 1 No. 1, 2014.

Purwanto, Yedi, Islam Mengutamakan Ilmu Pengetahuan dan Teknologi, Jurnal Sosioteknologi Institut Teknologi Bandung, Edisi 22 Tahun 10, 2013.

Posha, Beti Yanuri, Perkembangan Islam di Indonesia Pasca Kemerdekaan, Jurnal Historia, Vol. 3 No. 2, 2015.

R. Merkel ., Boer G., Fegert J., Galert T., Hartmann D., Nuttin B., et al. Intervening in the Brain. Changing Psyche and Society. Heidelberg: Springer, 2007

Rajab, Muhammad, Dakwah dan Tantangannya dalam Media Teknologi Komunikasi, Jurnal Dakwah Tabligh, Vol. 15 No. 1, 2014. 
Sardar, Ziauddin, Tantangan Dunia Islam Abad 21 Menjangkau Informasi, Bandung: Mizan, 1996, hal. 16-17

Shepard, William E., Islam and Ideology: Towards a Typology, International Journal of Middle East Studies, (Published by: Cambridge University Press, Vol. 19, No. 3, 1987.

Sutton, Brian P. Sutton, The Effects of Technology in Society and Education, A Thesis submitted to the Department of Education and Human Develop- ment of the State University of New York College, Spring 2013, h. 4 Erwin Hafid, The Early of Islam in Indonesia, Journal of JICSA, Vol. 1 No. 2, 2012.

Soewito Sutasoma Santoso, Study Old Javanese Wajrayana, New Delhi, International Academy of Culture, 1975, hal. 578 - accessed on 18 $18^{\text {th }}$ of March 2018 from https:// en.m.wikipedia.org.

Ulwan, Abdullah Nasih, Silsilah Madrasah al-Du'at, Kairo : Dar al-Hadith, 2004. Cet.ke-1, hal.16

Umar, Ratnah, Metode Dakwah di Era Globalisasi, Jurnal Al-Tajdid STAIN Palopo, Vol. 1, 2016 - accessed on 19th of March, 2018.

Yoeste, Rafael ., Goering, Sara, et al, Four Ethical Priorities for Neurotechnologies and AI. Nature : International Weekly Journal of Science, Volume. 551, Issue. 7679. 2017. 08 November 2017

Younes, Mohammad Bani ., Al- Zoubi , Samer, The Impact of Technologies on Society: A Review, IOSR Journal Of Humanities And Social Science (IOSR-JHSS), Vol. 20, Issue 2, Ver. V, 2015.

\section{Internet}

https://en.wikipedia.org/wiki/Indonesian_National_Revolution - Accessed on March $5^{\text {th }}, 2018$.

https://serbasejarah.files.wordpress.com/2012/12/setelah-dia-pergi- soeharto.pdf, Tempo Edisi Khusus Suharto, Madu dan Racun Sepuluh Tahun Lalu, hal. 23 - diakses pada tanggal 9 Maret 2018. 